\title{
ORIGINAL
}

\section{Background Radioactivity of Soil in Wakasa Bay Area (Southern Fukui Prefecture)}

\author{
Kazuko Megumi*,*1, Tadashi Tsujimoto,**,*2, \\ Takashi OKA ${ }^{* * *, * 1}$ and Kousuke KATSURAYAMA ${ }^{* * * * * 2}$ \\ (Received February 18, 1985) \\ (Accepted July 4, 1985)
}

\begin{abstract}
Soil samples of surface layer were collected in Wakasa Bay area which is composed of various geologic properties. Concentrations of background radionuclides in soil samples were determined by $\gamma$-ray spectrometry with a coaxial type and a planer type of $\mathrm{Ge}(\mathrm{Li})$ detectors. The spectra of soil samples obtained by X-ray diffraction analysis show the characteristic composition of minerals based on the geologic properties of their mother's rocks. The concentrations of ${ }^{238} \mathrm{U},{ }^{226} \mathrm{Ra},{ }^{228} \mathrm{Ra}$ and ${ }^{40} \mathrm{~K}$ in soil roughly correspond to the geologic properties. The highest concentrations of these four nuclides are the soil collected from granitic zone and next comes the soil from paleozoic zone. For homologous soil from granite and paleozoic the ${ }^{40} \mathrm{~K}$ contents decrease with increasing surface area, respectively. A good correlation between the ${ }^{137} \mathrm{Cs}$ contents and the unsupported ${ }^{210} \mathrm{~Pb}$ contents was found in the soil samples of surface layer.
\end{abstract}

KEY WORDS: background radioactivity, soil, Wakasa Bay area, mineral composition, geologic properties, natural radioactivity

\section{INTRODUCTION}

Knowledge of natural background radiation level is important not only in health physical research but in geoscientific research. It is well known that terrestial radiation originates in crustal materials and natural environmental radiation varies with geology and geography. ${ }^{1-3)}$ There have been many reports concerning distribution of natural radionuclides in rocks relating to their geologic properties ${ }^{1-7}$ ) and distribution of natural radionuclides in soil is usually assumed to be the same as that of their mother's rocks. A few investigations have been made concerning the distributions of natural radionuclides in relation to their

*1 恵 和子, $* *$ 辻本 忠, $* * *$ 岡 喬, $* * * *$ 桂山幸典

*1 Radiation Center of Osaka Prefecture; Shinkecho, Sakai-shi, Osaka-fu, 593.

大阪府立放射線中央研究所；堺市新家町704（开593）

*2 Research Reactor Institute of Kyoto University; Kumatori-cho, Sennan-gun, Osaka-fu, 590-04. 京都大学原子炉実験所; 大阪府泉南郡熊取町野田 ( T590-04) mineral compositions in soil over the ground. ${ }^{8-11)}$ Detailed information about the distribution of natural radionuclides in soil is also necessary from a view point of an environmental radioactive monitoring.

Area of southern Fukui Prefecture which surrounds Wakasa Bay is composed of various geologic properties: granite, paleozoic, andesites, ultrabasic rock, yakuno intrusive rocks, alluvium. Radioactive fallout in this area, which is on the Japan Sea side, near the Asian continent, dus to the old nuclear explosion tests deposited much compared with that on the side of the Pacific Ocean. The highest level of natural radiation in Japan was found in this area. ${ }^{1)}$ A several nuclear power plants are constructed.

Soil samples were collected on fifty seven sites in this area and some investigations were made concerning the concentrations of uranium series nuclides $\left({ }^{238} \mathrm{U},{ }^{226} \mathrm{Ra},{ }^{210} \mathrm{~Pb}\right)$, thorium series nuclides $\left({ }^{228} \mathrm{Ra}\right),{ }^{40} \mathrm{~K}$ and ${ }^{137} \mathrm{Cs}$ in soil in relation to their mineral compositions, their surface area and their ignition loss. 


\section{EXPERIMENT}

The samples of soil were collected from the two layers of $0-5 \mathrm{~cm}$ and $5-10 \mathrm{~cm}$ on fifty seven sites in the zones of granite, paleozoic, andesite, ultrabasic rock, yakuno intrusive rock and alluvium classified in a geologic map as shown in Fig. 1. Soil samples were collected using an iron sampler $8 \mathrm{~cm}$ in a diameter and is dried in an oven at $110^{\circ} \mathrm{C}$ for 24 $\mathrm{hr}$. The part of the sample of larger than 10 mesh is excluded by sieving and $120 \mathrm{~g}$ of dried sample are packed in a disk-shaped plastic case $9 \mathrm{~cm}$ in diameter and $2 \mathrm{~cm}$ in height. Each sample is subjected to $\gamma$-ray spectrometer with a planer type $\mathrm{Ge}(\mathrm{Li})$ detector $(16 \mathrm{~mm}$ in diameter and $5.13 \mathrm{~mm}$ in thickness) and a coaxial type of $\mathrm{Ge}(\mathrm{Li})$ detector (effective volume $50 \mathrm{ml}$ ). In order to reduce a background counting rate the $\mathrm{Ge}(\mathrm{Li})$ detectors are surrounded with shielding materials. ${ }^{8)}$ The activities of ${ }^{238} \mathrm{U}$ and ${ }^{210} \mathrm{~Pb}$ are determined by using the planer type $\mathrm{Ge}(\mathrm{Li})$ detector from photopeaks due to $63.1 \mathrm{keV}$ of ${ }^{234} \mathrm{Th}$ (daughter nuclide of ${ }^{238} \mathrm{U}$ ) and its $46.5 \mathrm{keV}$, respectively. (Even if uranium is chemically separated, 10 months is long enough to recover $99.9 \%$ of the equilibrium between ${ }^{238} \mathrm{U}$ and ${ }^{234} \mathrm{Th}$ (half-life 24.1 days) ). The activity of ${ }^{226} \mathrm{Ra},{ }^{228} \mathrm{Ra}\left({ }^{228} \mathrm{Ac}\right)$ and ${ }^{40} \mathrm{~K}$ are determined by using the coaxial $\mathrm{Ge}(\mathrm{Li})$ detector from the photo- peaks due to $609 \mathrm{keV}$ of ${ }^{214} \mathrm{Bi}, 911 \mathrm{keV}$ and 1.46 $\mathrm{MeV}$, respectively. The ${ }^{137} \mathrm{Cs}$ is determined from the photopeak due to $662 \mathrm{keV}$ of ${ }^{137 \mathrm{~m} B a}$. A reference sample by NBL (the New Brunswick Laboratory of the Atomic Energy Commission) is used as the standard for the activity determination.

$\mathrm{X}$-ray spectra are measured for each dried sample after disaggregating in an agate motar. Powder X-ray diffraction analysis is performed using copper radiation and nickel filter to determine mineral compositions. ${ }^{12,13)}$

The surface area of soil particles is determined by rapid surface area analysis using low-temperature nitrogen adsorption. ${ }^{14)}$

Each sample of ignition loss is determined from the percentage of loss in weight after that the dried sample of $1 \mathrm{~g}$ is kept at $1,000^{\circ} \mathrm{C}$ for $1 \mathrm{hr}^{15)}$ and an ignition loss is considered as a content of organic matter.

\section{RESULT AND DISCUSSION}

\section{Mineral composition}

Figure 2 shows a typical X-ray diffraction spectrum of soil sample collected from zones of granite, paleozoic, yakuno intrusive rocks, ultrabasic rocks and andesine classified on a geologic map, respectively. Peaks due to quartz, feldspar, illite, kaolinite and chlorite are seen in a spectrum

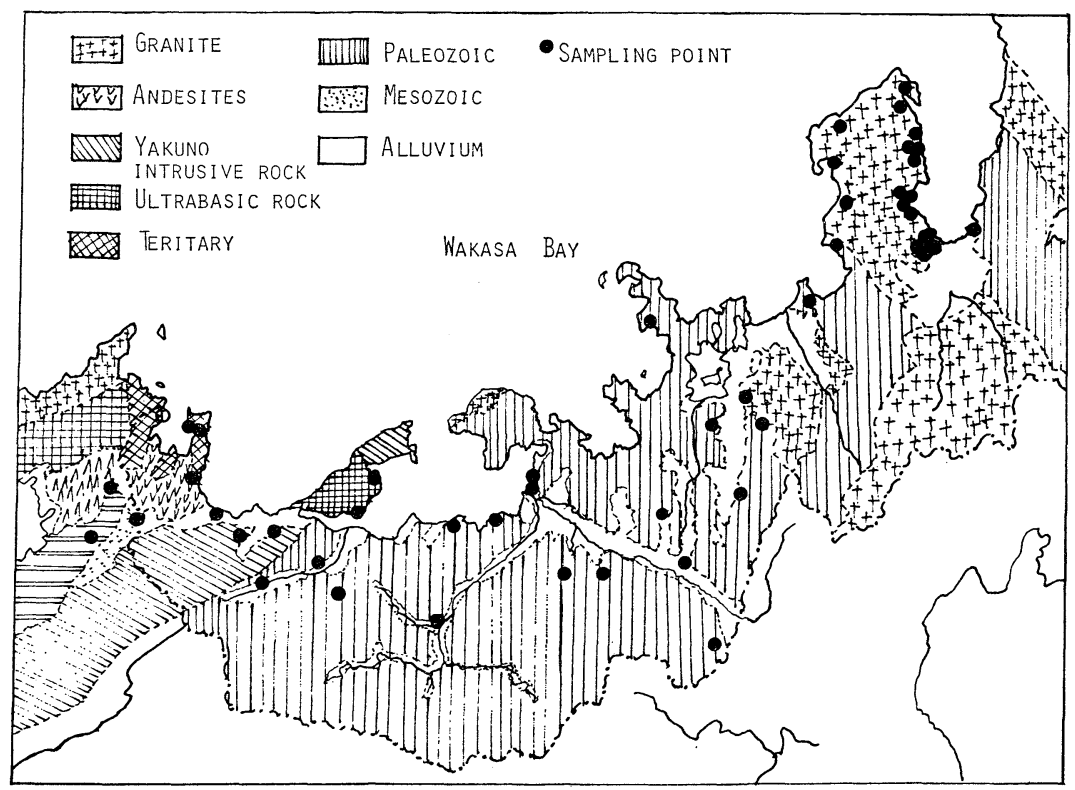

Fig. 1 Geologic map of the Wakasa Bay area showing the locations of sampling site. 


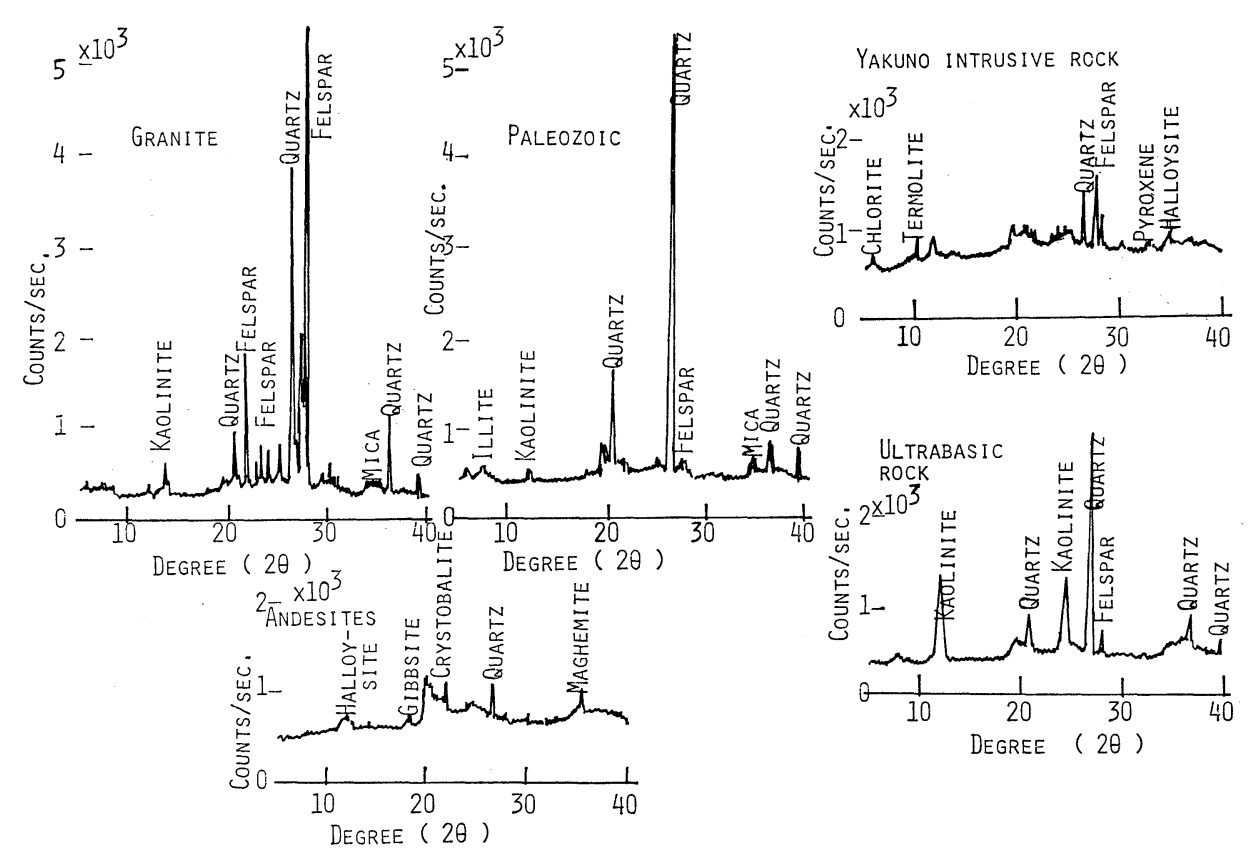

Fig. 2 Typical X-ray diffraction spectra of the soil samples collected from the zones of granite, paleozoic, yakuno intrusive rocks, ultrabasic rocks and andesine classified on a geologic map.

of soil collected from granite zone on the map. As the samples of soil from paleozoic zone were well weathered, clear peak due to quartz which is resistance to weathering and peaks due to illite, chlorite and kaolinite are shown in the spectrum of soil described above. Peaks due to pyroxene, chlorite, termolite, quartz are seen in a spectrum of soil collected from a zone of intrusive rocks. Ultrabasic rock is affected by desilication and peaks due to kaolinite and quartz are shown in its spectrum of soil. The peaks due to crystobalite and maghemite are also seen in that of soil collected from zone of andesites.

\section{Natural radioactivity}

Relationship between the concentrations of ${ }^{238} \mathrm{U}$ and ${ }^{226} \mathrm{Ra},{ }^{226} \mathrm{Ra}$ and ${ }^{228} \mathrm{Ra}$ are shown in Fig. 3. An arrangement in a descend order of the concentrations of these nuclides roughly are that of soil from granite, paleozoic, andesites, yakuno intrusive rocks and ultrabasic rocks. The ${ }^{226} \mathrm{Ra}$ activity is approximately equal to the ${ }^{238} \mathrm{U}$ activity in the soil samples except a few soil samples from granite. A soil sample containing $5.1 \mathrm{pCi} / \mathrm{g}$ of ${ }^{238} \mathrm{U}$ contains highly mica in which uranium is well known to be maldistributed. ${ }^{13)}$ A few soil samples con- taining $3-4 \mathrm{pCi} / \mathrm{g}$ of ${ }^{238} \mathrm{U}$ were collected from vegetable field and paddy field and these rather high contents of uranium are due to chemical fertilizer. ${ }^{15)}$

The activity ratio of ${ }^{228} \mathrm{Ra}$ to ${ }^{226} \mathrm{Ra}$ is nearly unity in the soil samples except that from granite. These ratios are smaller than unity in two soil samples for the high uranium contents as described above. The activity ratios of ${ }^{228} \mathrm{Ra}$ to ${ }^{226} \mathrm{Ra}$ in the soil samples from garanite are larger than unity and this reason seems that uranium which is a precursor of ${ }^{226} \mathrm{Ra}$ moves relative to thorium which is a precursor of ${ }^{228} \mathrm{Ra}$.

The radioactive relationships between ${ }^{40} \mathrm{~K}$ and ${ }^{238} \mathrm{U}$ or ${ }^{228} \mathrm{Ra}$ are shown in Fig. 4. The samples of two which show the highest values in the concentration of ${ }^{40} \mathrm{~K}$ content clearly orthoclase. The samples from granite show nearly the same value as the samples from the others in the activity ratios of ${ }^{238} \mathrm{U}$ ( $\fallingdotseq{ }^{226} \mathrm{Ra}$ as shown in Fig. 3(a) ) to ${ }^{40} \mathrm{~K}$ and, however, the activity ratio of ${ }^{228} \mathrm{Ra}$ to ${ }^{40} \mathrm{~K}$ in the sample from granite is larger than those of samples from others. It is considered that ${ }^{228} \mathrm{Ra}$ contents in soil samples from granite are high compared with the ${ }^{238} \mathrm{U},{ }^{226} \mathrm{Ra}$ and ${ }^{40} \mathrm{~K}$ contents. 


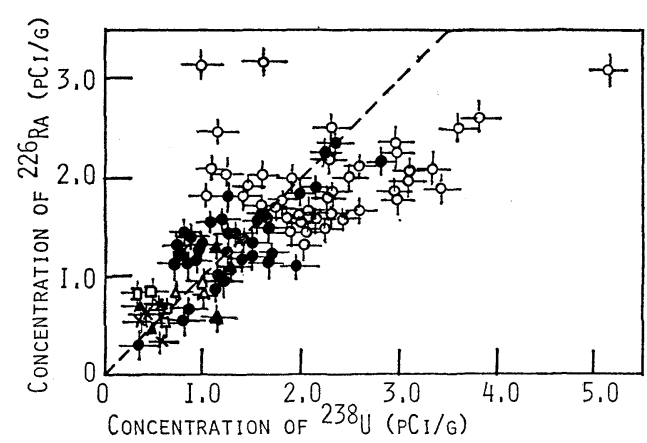

(a)

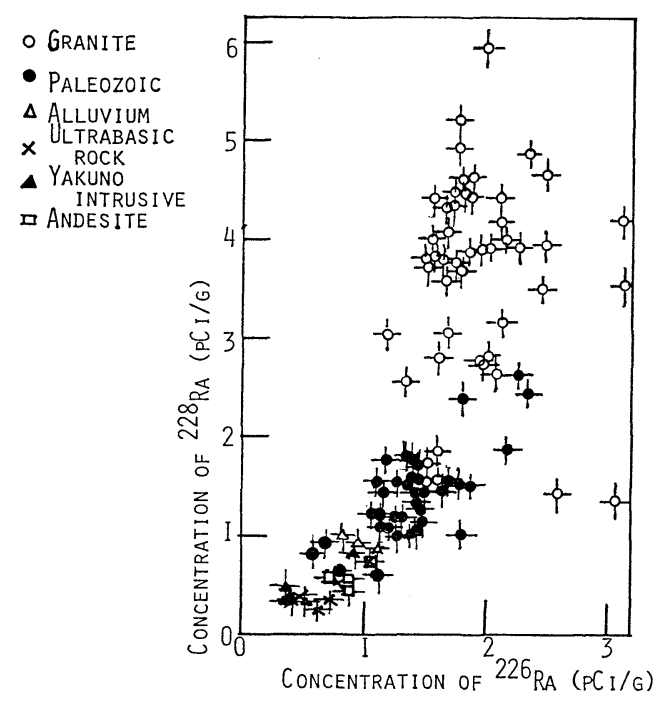

(b)

Fig. 3 Relationship between the concentrations of ${ }^{238} \mathrm{U}$ and ${ }^{226} \mathrm{Ra},{ }^{226} \mathrm{Ra}$ and ${ }^{228} \mathrm{Ra}$ in the soil samples collected from the two layers of $0-5$ and $5-10 \mathrm{~cm}$.

This fact may also be based on ${ }^{232} \mathrm{Th}$ which is a precursor of ${ }^{228} \mathrm{Ra}$.

We had reported that for an homologous soil, resulting from progressive weathering, which is free from the clay consisting of three-layer units, the ${ }^{40} \mathrm{~K}$ contents decrease with increasing their surface area. ${ }^{10)}$ As shown in Fig. 5, for the soil samples which hardly content the clay of montmorillonids and illites, the ${ }^{40} \mathrm{~K}$ contents in samples collected from the zones of granite and paleozoic decrease with increasing their surface area, respectively. The fact described above corresponds to the fact that the alkali metal ions and those of the alkaline earths are for the most part carried away in solution by erosion. ${ }^{13)}$

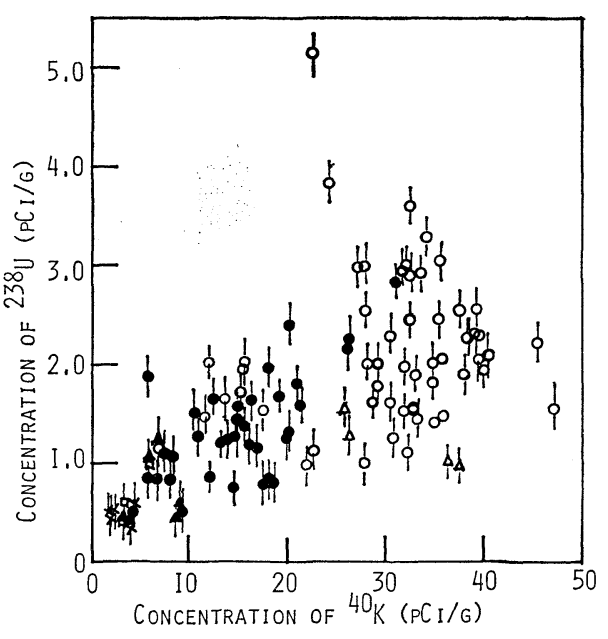

(a)

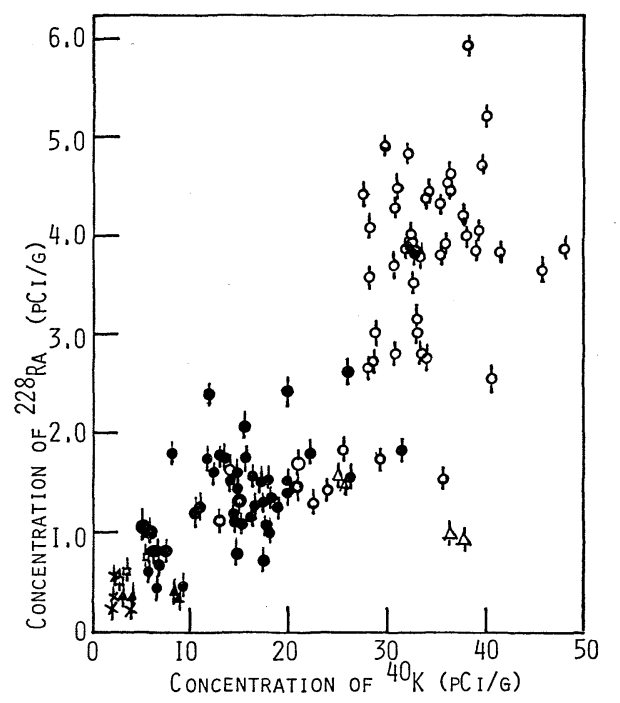

(b)

Fig. 4 The contents of ${ }^{238} \mathrm{U}$ and ${ }^{228} \mathrm{Ra}$ as a function of the ${ }^{40} \mathrm{~K}$ contents in the soil samples collected from the two layers of $0-5$ and $5-10 \mathrm{~cm}$.

\section{Relation between the ${ }^{137} \mathrm{Cs}$ content and ${ }^{210} \mathrm{~Pb}$ content}

The ${ }^{137} \mathrm{Cs}$ and ${ }^{210} \mathrm{~Pb}$ contents in the samples of two soil layers in the depth of $0-5 \mathrm{~cm}$ and $5-10 \mathrm{~cm}$ are nearly equivalence for soil samples collected in vegetable and rice fields and sandy beaches, because of mixing of the two layers. For the samples collected in lots grown with bamboo, grass or turf, these contents in the samples of down layer are 


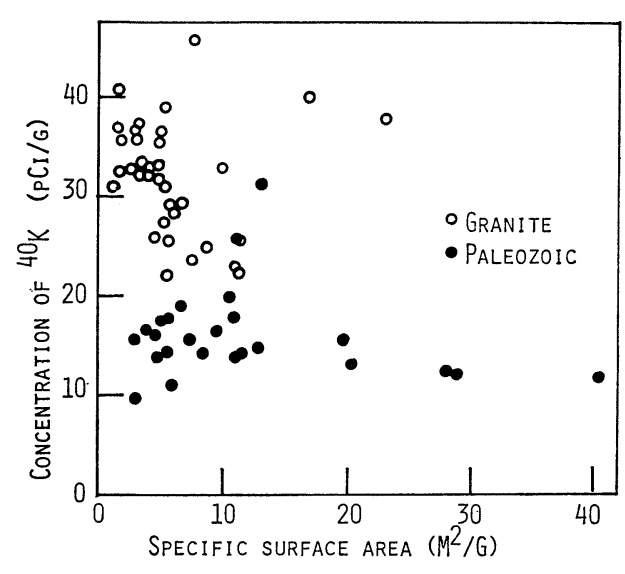

Fig. 5 Concentrations of ${ }^{40} \mathrm{~K}$ as a function of the surface area of soil collected from the zones of granite and paleozoic classified on a geologic map.

rather high because of that solution containing these nuclides flow down-wards with their roots. These concentrations in the two soil layers of samples except the described above are different from each other.

In Fig. 6 is shown a relationship between the ${ }^{137} \mathrm{Cs}$ contents and the contents of unsupported ${ }^{210} \mathrm{~Pb}$, i.e., ${ }^{226} \mathrm{Ra}$ supplied ${ }^{210} \mathrm{~Pb}$ has been subtracted from the total ${ }^{210} \mathrm{~Pb}$. Some part of gaseous ${ }^{222} \mathrm{Rn}$ produced from ${ }^{226} \mathrm{Ra}$ in soil escapes to the air and the content of ${ }^{210} \mathrm{~Pb}$ which is a decay product of ${ }^{222} \mathrm{Rn}$ may be a little bit less than the ${ }^{226} \mathrm{Ra}$ content. However, the contents of the total ${ }^{210} \mathrm{~Pb}$ are mostly high compared with the difference between the ${ }^{226} \mathrm{Ra}$ contents and the contents of its supplied ${ }^{210} \mathrm{~Pb}$. Then radioactivity equilibrium between the contents of ${ }^{226} \mathrm{Ra}$ and ${ }^{210} \mathrm{~Pb}$ in soil is assumed to have been established and the content of unsupported ${ }^{210} \mathrm{~Pb}$ is determined by the subtraction of the ${ }^{226} \mathrm{Ra}$ content from the total ${ }^{210} \mathrm{~Pb}$. It is considered that ${ }^{222} \mathrm{Rn}$ exhaled from the ground and its decay products stay in the atmosphere and deposit on the ground with a rainout and a dry fallout. ${ }^{137} \mathrm{Cs}$ which is produced by the nuclear explosion tests also deposits on the ground with a rainout and a dryout. In this figure is also shown the values of the contents in the samples collected from the place on which the fallout depositions are easily concentrated. It is observed that for the soil samples collected in 1881-1983 from the two layers in the depth of $0-5$ and $5-10 \mathrm{~cm}$, a relation in activities of the ${ }^{137} \mathrm{Cs}$ to the unsupported ${ }^{210} \mathrm{~Pb}$ may be expressed by the following formula;

$C=0.29 B-0.24$

$C$ : the ${ }^{137} \mathrm{Cs}$ content $(\mathrm{pCi} / \mathrm{g})$

$B$ : the unsupported ${ }^{210} \mathrm{~Pb}$ content $(\mathrm{pCi} / \mathrm{g}$ )

This correlation may be inapplicable for the soil samples collected after several years, because of that unsupported ${ }^{210} \mathrm{~Pb}$ always deposits and, however, ${ }^{137} \mathrm{Cs}$ almost deposited until 1972 and migrates downwards in the ground, and the ${ }^{137} \mathrm{Cs}$ content in soil decreases with year according to its half life also. This relation in activities of the two nuclides is mainly based on the datum about soil enriched in organic matter and then, these two nuclides are mainly considered to associate with organic matter. ${ }^{16,17)}$ For estimating influence of an accident of nuclear energy plants, the levels of ${ }^{137} \mathrm{Cs}$ in soil are generally monitored. The contents of ${ }^{137} \mathrm{Cs}$ in the soil of $0-10 \mathrm{~cm}$ layer due to nuclear explosion tests can be estimated by this formula

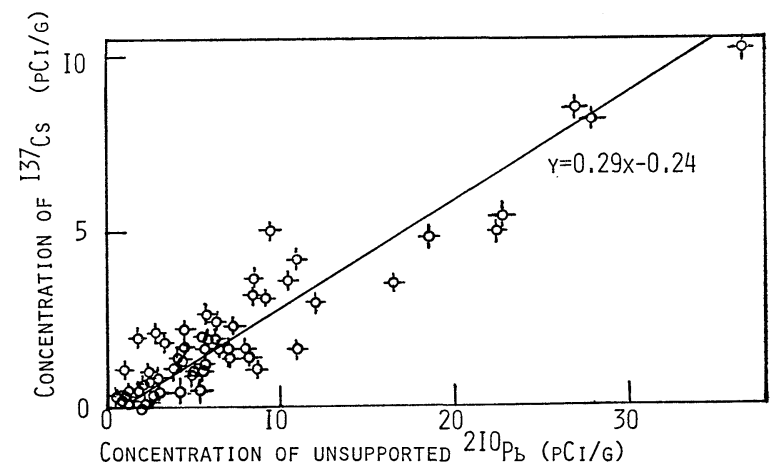

Fig. 6 A relationship between the ${ }^{137} \mathrm{Cs}$ contents and the contents of unsupported ${ }^{210} \mathrm{~Pb}$ in the soil samples collected from the two layers of $0-5$ and $5-10 \mathrm{~cm}$. 
with the unsupported ${ }^{210} \mathrm{~Pb}$. The levels of ${ }^{137} \mathrm{Cs}$ due to an accident of nuclear energy plant may be estimated.

\section{Ignition loss and the ${ }^{137} \mathrm{Cs}$ contents and the ${ }^{210} \mathrm{~Pb}$ contents}

In Fig. 7 is shown a relationship between ignition loss and the ${ }^{137} \mathrm{Cs}$ contents and the ${ }^{210} \mathrm{~Pb}$ contents, respectively. These contents have a tendency to increase with increasing of the ignition loss of sample for an each case of places having a similar value in the total depositions. ${ }^{16,17)}$ The following three places; the place of under trees is covered with dead leaves collected the fallout radioactivity,

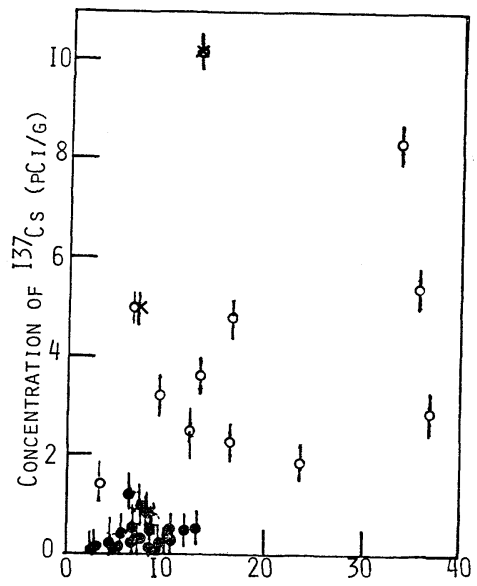

IGNITION LOSS (\%)

× rain water easily gathered

- under tREes

- bare land

(a)

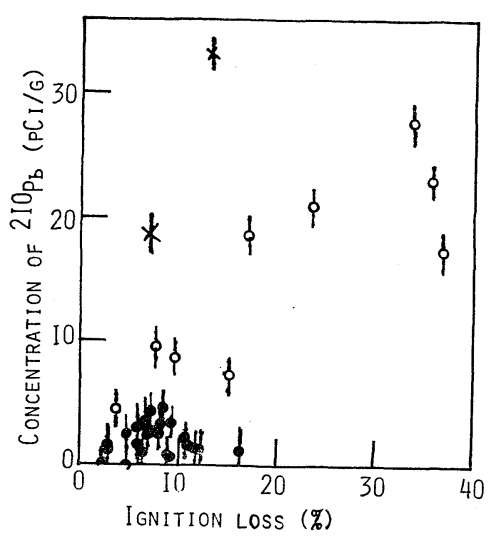

(b)

Fig. 7 The ${ }^{137} \mathrm{Cs}$ contents and the ${ }^{210} \mathrm{~Pb}$ contents as a function of ignition loss.

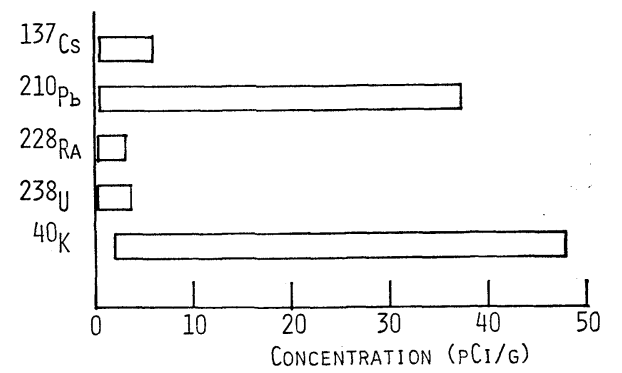

Fig. 8 A distribution of the concentrations of ${ }^{40} \mathrm{~K},{ }^{238} \mathrm{U},{ }^{226} \mathrm{Ra},{ }^{228} \mathrm{Ra},{ }^{210} \mathrm{~Pb}$ and ${ }^{137} \mathrm{Cs}$ in the soil samples collected from the two layers.
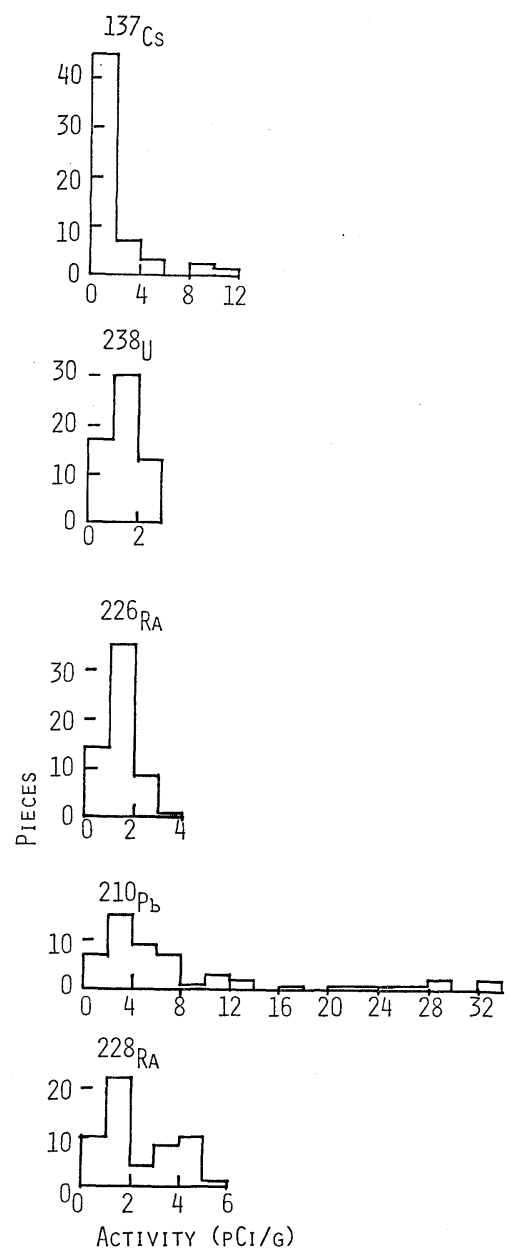

Fig. 9 The frequency of the concentrations of ${ }^{238} \mathrm{U},{ }^{226} \mathrm{Ra},{ }^{210} \mathrm{~Pb},{ }^{228} \mathrm{Ra}$ and ${ }^{137} \mathrm{Cs}$ in the soil samples of $0-5 \mathrm{~cm}$ layer. 
as rainout and dryout are adsorbed very much on surface of leaves; as rain water also carry fallout radioactivity, on place which rain water is easily gathered; the last place is bare land.

\section{Radioactivity of soil}

As shown in Fig. 8, a distribution of the ${ }^{40} \mathrm{~K}$ content is the widest in the contents of background radioactive nuclides. It is seen in Fig. 9 that the radioactive concentration of ${ }^{210} \mathrm{~Pb}$, which is a decay product of radon, is the highest in the background radioactivities of soil except that of ${ }^{40} \mathrm{~K}$.

\section{REMARKS}

It was found that mineral compositions of soil are based on the geologic properties of their mother's rocks and the contents of ${ }^{238} \mathrm{U},{ }^{226} \mathrm{Ra}$, ${ }^{228} \mathrm{Ra}$ and ${ }^{40} \mathrm{~K}$ in soil are characterized in geologic properties. For homologous soil from granite and paleozoic the ${ }^{40} \mathrm{~K}$ contents decrease with increasing surface area, respectively. It is observed that the radioactive concentration of ${ }^{210} \mathrm{~Pb}$ is the highest of background radioactivity in soil except that of ${ }^{40} \mathrm{~K}$. A good correlation between the ${ }^{137} \mathrm{Cs}$ and the unsupported ${ }^{210} \mathrm{~Pb}$ contents was found in soil samples in the depth of $0-10 \mathrm{~cm}$ and then, the activity of ${ }^{137} \mathrm{Cs}$ due to an accident of nuclear energy plants may be easily distinguish from that due to nuclear explosion tests using this correlation.

ACKNOWLEDGEMENTS: The authors wish to express their gratitude to Dr. S. Abe of National Institute of Radiological Sciences, Dr. Y. Nakashima of Nagoya University and Dr. S. Kimura of Osaka College of Pharmacy for their useful advices. The authors are also indebted to Messrs. K. Yamazaki, I. Urabe, K. Okamoto and T. Yoshimoto for useful discussions and collecting samples.

\section{REFERENCES}

1) K. Fujitaka, S. Abe and K. Fujimoto; Analysis of contour map of natural radiation in Japan, J. Nucl. Sci. Technol., 18, 727 (1981).

2) K. FujitaKa, S. ABE and K. Fujimoto; Distribution of natural radiation in Japan in relation to geologic properties, J. Nucl. Sci. Technol., 18, 222 (1981).

3) K. Katsurayama et al.; Natural background radiation (radioactivity) in Wakasa district (preliminary report); Environmental radiation, The committee on environmental radiation research
(Atomic Energy Society of Japan) (1984).

4) Y. Miyake, Y. Sugiura and Y. Hirao; Uranium, thorium and potassium contents in granitic and basaltic rocks in Japan, Second International Symposium on the Natural Radiation Environment, U.S. Energy Research and Development Administration, Washington, D.C. (1975).

5) S. Nishimura and K. Katsura; Uranium, thorium and potassium content of Rokko granitic bodies, Hyogo prefecture, J. Jpn. Assoc. Min. Pet. Econ. Geol., 62, 44 (1969).

6) S. Nishimura, S. Yagi, K. Katsura, Z. Hatsuda and T. Asayama; Uranium, thorium and potassium content of rocks in Japan, J. Jpn. Min. Pet. Econ. Geol., 59, 206 (1968).

7) K.S. HeIER and J.J.W. Rogers; Radiometric determination of thorium uranium and potassium in basalts and in two differntiation series, Geochim. Cosmochim. Acta, 27, 137 (1963).

8) K. Megumi and T. Mamuro; Concentration of uranium series nuclides in soil particles in relation to their size-Basic information for monitoring of radioactive contamination in soil, Hoken Butsuri, 12, 181 (1977).

9) K. Megumi; Radioactive disequilibrium of uranium and actinium series nuclides in soil, J. Geophys. Res., 84, 3677 (1979).

10) K. Megumi, T. Oka, K. Yaskawa and M. SakaNOUE; Contents of natural radioactive nuclides in soil, J. Geophys. Res., 8710857 (1982).

11) L.M. Morera-NordemanN; Distribution of uranium in soil profiles of Bahia state, Bragil, Soil Sci., 127, 275 (1979).

12) G.W. BRINDLEY; " $X$-ray Identification and Crystal Structure of Clay Minerals," p. 473 (1953), Mineralogical Society, London.

13) B. Meason; "Principles of Geochemistry," p. 96, 146, 173 (1966), John Wiley \& Sons, New York.

14) S.J. GREGG and K.S.W. SING; "Adsorption Surface Area and Porosity" (1967), Academic Press, New York.

15) T.Y. Wu, C.L. Tseng and P.S. Weng; Determination of uranium, thorium, radium and potassium in commercial products, Radioisotopes, 27, 30 (1978).

16) I.L. Brisbin, Jr., R.J. Beyers, R.W. Dapson, R.A. Geiger, J.B. Gentry, J.W. GibBons, M.H. SMITH and S.K. Woods; Patterns of radiocesium in the sediments of a stream channel contaminated by production reactor effluents, Health Phys., 27, 19 (1974).

17) M. Yamamoto, T. Tani and M. Sakanoue; Characteristics of fall-out plutonium in soil, $J$. Radiat. Res., 22, 134 (1981). 